\title{
Roles of the Escherichia coli Heat Shock Sigma Factor 32 in Early and Late Gene Expression of Bacteriophage T4
}

\author{
MARK W. FRAZIER AND GISELA MOSIG* \\ Department of Molecular Biology, Vanderbilt University, Nashville, Tennessee 37235
}

Received 24 August 1987/Accepted 22 December 1987

\begin{abstract}
We have analyzed early and late $\mathrm{T} 4$ gene expression at the levels of transcription and translation in $\mathrm{rpoH}^{+}$ (sigma $32^{+}$) and rpoH mutant cells infected under heat shock conditions. We found, as expected, that Escherichia coli cells must be adapted before infection to high temperature by the heat shock response to allow early T4 transcription, subsequent late gene expression, and progeny production at $42^{\circ} \mathrm{C}$. Unexpectedly, we found in addition that when rpoH mutant (sigma 32 mutant) cells were shifted from 30 to $42^{\circ} \mathrm{C} 10$ min after infection, late T4 genes were not expressed, even though DNA synthesis appeared to be normal.
\end{abstract}

We have investigated the effects of the Escherichia coli heat shock response on bacteriophage $\mathrm{T} 4$ development since this response has important consequences for design and interpretation of experiments at high temperatures (e.g., $42^{\circ} \mathrm{C}$ ), a condition often used with temperature-sensitive mutants. In our early experiments on T4 DNA replication, using temperature-sensitive host mutants (13) or phage mutants (14) and their wild-type parents, we observed that host cells had to be adapted to $42^{\circ} \mathrm{C}$, the restrictive temperature, before infection to obtain reproducible results (most data not shown). The discovery of the heat shock response suggested a possible reason for previous inconsistencies.

Transcription of T4 depends on $E$. coli core RNA polymerase which, together with various $E$. coli or phageencoded transcription factors, recognizes different classes of phage promoters $(2,4)$. T4 early promoters require the major $E$. coli sigma factor, sigma 70 (17). The enhanced association of a minor sigma factor, sigma $32(E$. coli gene product [gp] $r p o H$ ), with RNA polymerase and the concomitant reduction in sigma 70 levels and activity after cells are shifted from 30 to $42^{\circ} \mathrm{C}$ (heat shock conditions) (19) is critical in the induction of $E$. coli heat shock genes $(6,7,16,25)$. The transcription of $r p o D$ (sigma 70) from a heat shock promoter under these conditions is thought to be essential, among other factors, for the replenishment of sigma 70 and the resumption of global transcription (and therefore T4 transcription) after cells are adapted to higher temperatures $(15,21)$.

Since T4 infection turns off expression of all host genes (20), these considerations imply that sigma 70 is in low supply for early $\mathrm{T} 4$ transcription when wild-type or $r p o H$ mutant host cells are shifted to a high temperature exactly at the time of infection. Thus, we expected that expression of early T4 genes, and consequently the entire T4 transcriptional program, might be defective under these conditions. Sufficient sigma 70 should be available for $\mathrm{T} 4$ transcription if rpoH ${ }^{+}$cells have been adapted to higher temperatures before infection. In contrast, in hosts that are defective in the heat shock sigma factor (sigma 32), adaptation and sigma 70 replenishment cannot occur, regardless of the time elapsed after the heat shock. Thus, if the temperature is raised before infection, $r p o H^{+}$cells should allow T4 tran-

\footnotetext{
* Corresponding author.
}

scription but $r p o H$ mutant cells should not. Our first sets of results are consistent with these expectations.

Because late $\mathrm{T} 4$ promoters are recognized by a T4-encoded sigma factor, sigma gp55, and there is conflicting evidence whether they require host sigma factors $(10,26)$, we also tested the effects of the host $r p o H$ mutation when cells were shifted from 30 to $42^{\circ} \mathrm{C} 10 \mathrm{~min}$ after infection, i.e., at a time when all the factors required for late gene expression, including gp55, should have been synthesized (17). We found that the heat shock sigma factor 32 is required for late transcription when infected cells are heat shocked at a time when T4 sigma gp 55 has already been synthesized.

Expression of early T4 genes. Shifting the temperature at the time of infection drastically reduced $\mathrm{T} 4$ prereplicative and late proteins (Fig. 1), and consequently progeny production (Table 1), in both $\mathrm{rpoH}^{+}(E$. coli SC122 and B strains were tested; only SC122 results are shown) and $r p o H(\mathrm{~K} 165)$ mutant host cells (Fig. 1, lanes 1 and 2). If $\mathrm{rpoH}^{+}$cells were shifted to $42^{\circ} \mathrm{C}$, grown at this temperature for $30 \mathrm{~min}$ (allowing heat shock induction of sigma 70), and then infected, T4 early proteins accumulated (Fig. 1, lane 5). In contrast, when $r p o H$ mutant cells, which cannot synthesize sigma 70 in response to heat shock, were infected under these same conditions, all early $\mathrm{T} 4$ proteins were drastically reduced (Fig. 1, lane 6), and few progeny appeared (Table 1). Early and late protein synthesis as well as progeny production were similar in $r p o H$ mutant cells and $\mathrm{rpoH}^{+}$cells grown and infected at $30^{\circ} \mathrm{C}$ (Fig. 1 and Table 1).

To test whether these effects correlate with altered transcription, we analyzed, as an example, the transcripts of the gene 69-oriA region with a probe that does not hybridize to late transcripts (Fig. 2) (12). In this region, a 1,050-nucleotide transcript is initiated from an early promoter and a 600-nucleotide transcript is initiated from a middle promoter (12). Figure 2 shows that the abundance of both transcripts was greatly reduced when $r p o H^{+}$cells were shifted to $42^{\circ} \mathrm{C}$ at the time of infection. As expected, the abundance of these transcripts was reduced in $r p o H$ mutant cells regardless of the time of temperature shift. Together, these results indicate that a successful heat shock response is required for T4 early transcription at high temperature. They are consistent with the idea that sigma 32 out-competes sigma 70 upon temperature shift $(6,7,16,19,25)$ and that $r p o H$ mutant cells 


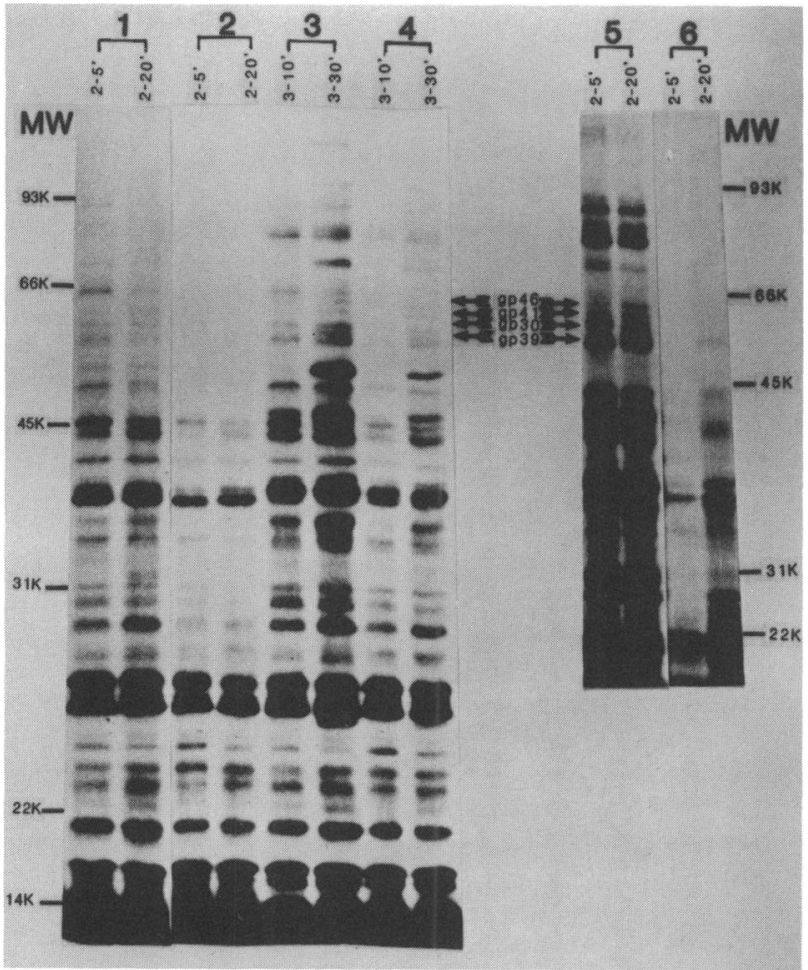

FIG. 1. T4 proteins synthesized when host cells were shifted to $42^{\circ} \mathrm{C}$ before or at the time of infection. $\mathrm{rpoH}^{+}$and $\mathrm{rpoH}$ mutant cells (SC122 and $\mathrm{K} 165$, respectively; a gift of $\mathrm{F}$. Neidhardt) were grown at $30^{\circ} \mathrm{C}$ to $10^{8}$ cells per $\mathrm{ml}$, concentrated to $10^{9}$ cells per $\mathrm{ml}$, and infected with 10 wild-type T4 particles per cell. At the indicated times, cells were shifted from 30 to $42^{\circ} \mathrm{C}$. Control samples remained at $30^{\circ} \mathrm{C}$. Infected cells were pulse-labeled with ${ }^{3} \mathrm{H}$-labeled L-amino acids (specific activity, $5 \mu \mathrm{Ci} / \mathrm{ml}$ ) for two different times after infection (indicated at top) and chased with excess Casamino acids. Infected cells were then lysed in Laemmli sodium dodecyl sulfatepolyacrylamide gel electrophoresis sample buffer (11). Labeled proteins were separated on $20 \%$ "low bis" polyacrylamide gels at pH 7.8 with a $5 \%$ stacking gel $(\mathrm{pH} 6.8)(1)$. Lanes: $1, \mathrm{rpoH}^{+}$cells shifted to $42^{\circ} \mathrm{C}$ at the time of infection; $2, r p o H$ mutant cells shifted to $42^{\circ} \mathrm{C}$ at the time of infection; $3, r p o H^{+}$cells grown and infected at $30^{\circ} \mathrm{C} ; 4, r p o H$ mutant cells grown and infected at $30^{\circ} \mathrm{C} ; 5, r p o H^{+}$ cells shifted to $42^{\circ} \mathrm{C} 30$ min before infection; $6, r p o H$ mutant cells shifted to $42^{\circ} \mathrm{C} 30 \mathrm{~min}$ before infection.

TABLE 1. T4 progeny production per infected cell

\begin{tabular}{clcccc}
\hline \multirow{2}{*}{ Host } & $\begin{array}{l}\text { Infecting } \\
\text { phage }\end{array}$ & \multicolumn{4}{c}{ Progeny per infected cell after shift at time ${ }^{a}$ : } \\
\cline { 3 - 6 } & $-30 \mathrm{~min}$ & $0 \mathrm{~min}$ & $10 \mathrm{~min}$ & No shift $^{b}$ \\
\hline rpoH $^{+}$ & Wild type & 43 & 2 & 50 & 85 \\
& dell2 & 29 & 4 & 40 & 44 \\
$r p o H$ & Wild type & 6 & 3 & 7 & 90 \\
& dell2 & 0.06 & 0.12 & 33 & 39 \\
\hline
\end{tabular}

${ }^{a}$ Shift from 30 to $42^{\circ} \mathrm{C}$ at time after infection.

$b$ No shift $\left(30^{\circ} \mathrm{C}\right)$.

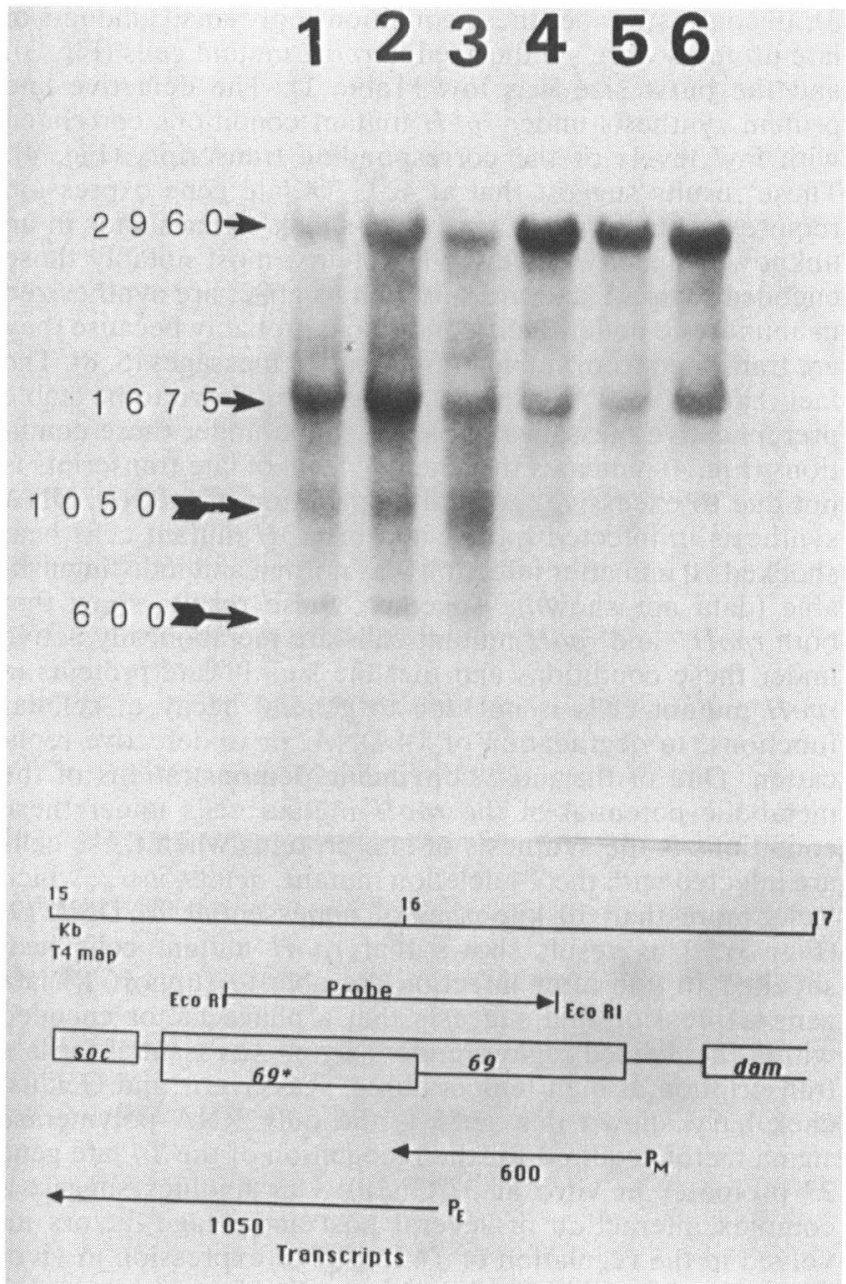

FIG. 2. Northern blot of early T4 RNA probed with the gene 69-oriA region of T4. $\mathrm{rpoH}^{+}$and $\mathrm{rpoH}$ mutant cells were infected with wild-type $\mathrm{T} 4$ under the conditions described in the legend to Fig. 1. RNA isolated from infected cells at $8 \mathrm{~min}$ after infection was separated and blotted as previously described (22). It was probed with RNA transcribed by SP6 RNA polymerase (Bethesda Research Laboratories, Inc.) from an EcoRI DNA fragment cloned into pSP64 (Promega Biotech). Transcription conditions were according to the directions of Promega Biotech. Infection conditions were as follows: lane $1, r p o H^{+}$cells grown and infected at $30^{\circ} \mathrm{C}$; lane $2, r p o H$ mutant cells grown and infected at $30^{\circ} \mathrm{C}$; lane $3, \mathrm{rpoH}^{+}$cells infected at $30^{\circ} \mathrm{C}$ and immediately shifted to $42^{\circ} \mathrm{C}$; lane $4, r p o H$ mutant cells infected at $30^{\circ} \mathrm{C}$ and immediately shifted to $42^{\circ} \mathrm{C}$; lane $5, r p o H^{+}$cells shifted to $42^{\circ} \mathrm{C} 30$ min before infection; lane $6, r p o H$ mutant cells shifted to $42^{\circ} \mathrm{C} 30 \mathrm{~min}$ before infection. The T4 transcripts of 1,050 and 600 nucleotides are marked with arrows, and the host rRNAs of 2,960 and 1,675 nucleotides are marked with arrowheads. 
fail to synthesize additional sigma 70 in response to heat shock.

Effects of heat shock at late times after infection. When infected $\mathrm{rpoH}^{+}$cells were shifted to a higher temperature 10 min after infection, at a time when T4 sigma gp 55 had been synthesized, T4 late protein synthesis appeared normal (Fig. 3 ). In contrast, under these conditions only small amounts of late proteins were synthesized in rpoH mutant cells (Fig. 3), and the burst size was low (Table 1). The defective late protein synthesis under $\mathrm{rpoH}$ mutant conditions correlated with low levels of the corresponding transcripts (Fig. 4). These results suggest that at $42^{\circ} \mathrm{C} \mathrm{T} 4$ late gene expression requires a functional $E$. coli heat shock sigma factor in an unknown capacity. A few T4 proteins, most notably those encoded by $u v s X$ and $u v s Y$ as well as gp32, are synthesized in abundance under these conditions, probably because they are translated from stable prereplicative messages $(5,8)$. The fact that the uvs $Y$ transcripts, which are known to be stable prereplicative messages (8), were stable under these conditions (Fig. 4) indicates that the low level of late transcripts is not due to excessive, general degradation of mRNA. DNA synthesis in infected $r p o H^{+}$and in $r p o H$ mutant cells heat shocked $10 \mathrm{~min}$ after infection was normal and indistinguishable (data not shown). Together, these results show that both $\mathrm{rpoH}^{+}$and $\mathrm{rpoH}$ mutant cells are metabolically active under these conditions and that the lack of late proteins in rpoH mutant cells is not due to general decay of cellular functions, to degradation of T4 DNA, or to defective replication. One of the most convincing demonstrations of the metabolic potential of the rpoH mutant cells under these conditions is the synthesis of late proteins when these cells are infected with the T4 deletion mutant, $\operatorname{del}(39-56) 12$, which lacks more than 10 kilobases of nonessential T4 DNA (9) (Fig. 3). This result shows that rpoH mutant cells heat shocked 10 min after infection are able to support T4 late gene expression and suggests that a phage factor encoded within the deleted region renders sigma 32 essential for late transcription at high temperatures. Kassavetis and Geiduschek have shown that gp55 is the only RNA polymerase sigma factor required for the recognition of the T4 late gene 23 promoter in vitro at $37^{\circ} \mathrm{C}(10)$. Our findings suggest a complex interaction of several host and phage factors involved in the regulation of T4 late gene expression in vivo. We are now trying to identify the putative factor(s), encoded in the nonessential region, that renders sigma 32 essential at $42^{\circ} \mathrm{C}$.

Since our experiments were done under conditions that prevented T4 transcription, they could not detect additional effects of $E$. coli heat shock proteins on subsequent steps of T4 development. For example, $\mathrm{rpoH}^{+}$cells that are heat shocked $5 \mathrm{~min}$ after infection do synthesize late $\mathrm{T} 4$ proteins, but these proteins are incorrectly assembled. The defect can be partially corrected by overproduction from a plasmid of the $E$. coli GroEL protein, a heat shock protein required for normal T4 assembly (24).

Our results provide an explanation for many differences in results obtained with the same $t s$ mutants under different conditions of infection. For example, T4 gene 32 mutants, which had been classified as being completely defective in DNA replication (18), undergo at least one round of DNA replication when cells are adapted to $42^{\circ} \mathrm{C}$ before infection (14).

Our unexpected observation that, at high temperature, development of phage T4 is affected by $E$. coli sigma factors 70 and 32, illustrates the complex interaction of this molecular parasite with its host throughout the viral life cycle.

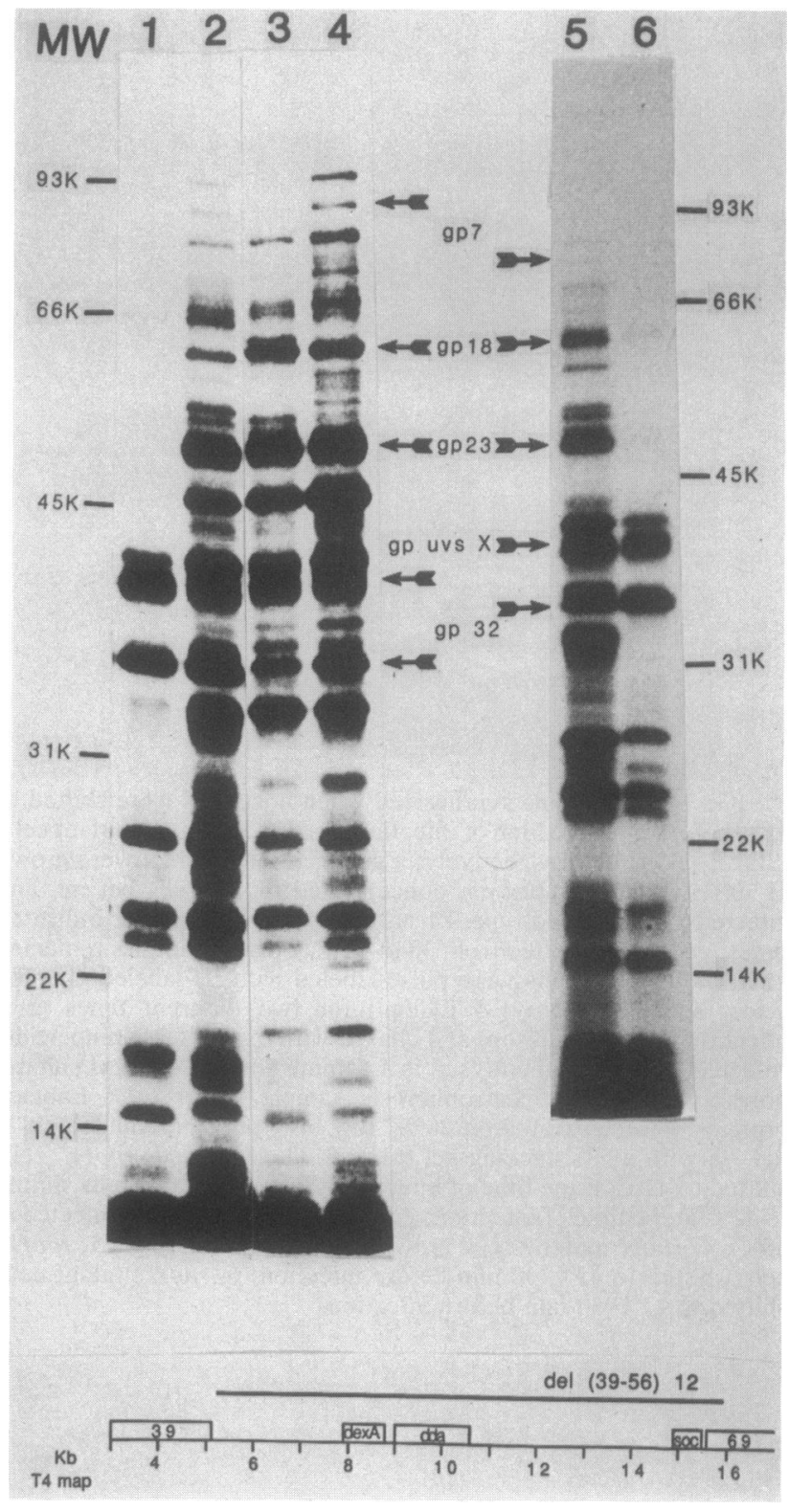

FIG. 3. T4 proteins pulse-labeled 15 to $20 \mathrm{~min}$ after infection when temperature was shifted to $42^{\circ} \mathrm{C} 10 \mathrm{~min}$ after infection. Cells were grown at $30^{\circ} \mathrm{C}$ to $10^{8}$ cells per ml, concentrated to $10^{\circ}$ cells per $\mathrm{ml}$, and infected with $10 \mathrm{~T} 4$ particles per cell. The proteins were separated as described in the legend to Fig. 1. Lanes: 1, rpoH mutant cells shifted to $42^{\circ} \mathrm{C} 10$ min after infection; 2 , control infected $r p o H$ mutant cells incubated at $30^{\circ} \mathrm{C} ; 3, r p o H^{+}$cells shifted to $42^{\circ} \mathrm{C}$ 10 min after infection; 4, infected $r p o H^{+}$cells incubated at $30^{\circ} \mathrm{C} ; 5$, rpoH mutant cells infected with $\operatorname{del}(39-56) 12 \mathrm{~T} 4$ and shifted to $42^{\circ} \mathrm{C}$ 10 min after infection; $6, r p o H$ mutant cells infected with wild-type T4 and shifted to $42^{\circ} \mathrm{C} 10 \mathrm{~min}$ after infection. 

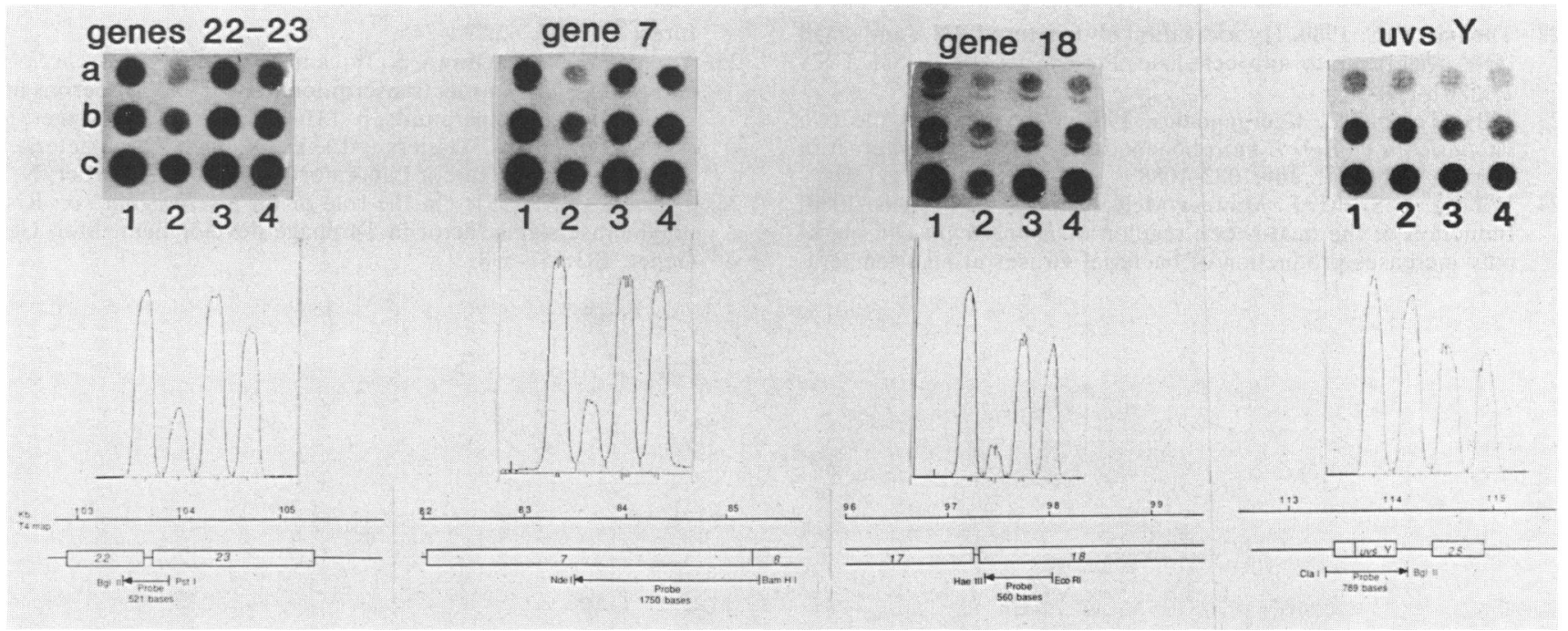

FIG. 4. Dot blots of T4 RNA isolated at $20 \mathrm{~min}$ after infection. Cells were grown to $3 \times 10^{8}$ cells per ml and infected with 10 wild-type T4 particles per cell. RNA was isolated as described (legend of Fig. 2). Total RNA was blotted into a nylon membrane in dots of $0.25,0.5$, and $1.0 \mu \mathrm{g}$ (lanes a, b, and c, respectively) as described (3). Gene-specific probes shown were prepared as described (legend of Fig. 2), transcribing pGL737 (gene 23), pGL7 (gene 7), pGL541 (gene 18) (all obtained from G. Lin, this laboratory), and pMGr800 (uvs Y; M. Guidl, this laboratory). Conditions were: lane $1, r p o H^{+}$cells shifted to $42^{\circ} \mathrm{C} 10 \mathrm{~min}$ after infection; lane $2, r p o H$ mutant cells shifted to $42^{\circ} \mathrm{C} 10 \mathrm{~min}$ after infection; lane 3, infected $r p o H^{+}$cells incubated at $30^{\circ} \mathrm{C}$; lane 4, infected $r p o H$ mutant cells incubated at $30^{\circ} \mathrm{C}$.

We thank Fred Neidhardt for E. coli SC122 and K165.

This work was supported by Public Health Service grant GM13221 to G.M. and Public Health Service training grant CA 09385 (both from the National Institutes of Health) and by the Natural Science Fund of Vanderbilt University.

\section{LITERATURE CITED}

1. Belfort, M. 1978. Anomalous behavior of bacteriophage lambda polypeptides in polyacrylamide gels: resolution, identification, and control of the lambda rex gene product. J. Virol. 28:270278.

2. Brody, E., D. Rabussay, and D. H. Hall. 1983. Regulation of transcription of prereplicative genes, p. 174-183. In C. K. Matthews, E. M. Kutter, G. Mosig, and P. B. Berget (ed.), Bacteriophage T4. American Society for Microbiology, Washington, D.C.

3. Cheley, S., and R. Anderson. 1984. A reproducible microanalytical method for the detection of specific RNA sequences by dot-blot hybridization. Anal. Biochem. 137:15-19.

4. Geiduschek, E. P., T. Elliott, and G. A. Kassavetis. 1983. Regulation of late gene expression, p. 189-192. In C. K. Matthews, E. M. Kutter, G. Mosig, and P. B. Berget (ed.), Bacteriophage T4. American Society for Microbiology, Washington, D.C.

5. Gorski, K., J.-M. Roch, P. Prentki, and H. M. Krisch. 1985. The stability of bacteriophage T4 gene 32 mRNA: a $5^{\prime}$ leader sequence that can stabilize mRNA transcripts. Cell 43:461-649.

6. Grossman, A. D., W. E. Taylor, Z. F. Burton, R. R. Burgess, and C. A. Gross. 1984. The htp R gene product of Escherichia coli is a sigma factor for heat shock promoters. Cell 38:383-390.

7. Grossman, A. D., Y.-N. Zhou, C. Gross, J. Heilig, G. E. Christie, and R. Calendar. 1985. Mutations in the rpoH (htpR) gene of Escherichia coli $\mathrm{K}-12$ phenotypically suppress a temperaturesensitive mutant defective in the sigma-70 subunit of RNA polymerase. J. Bacteriol. 161:939-943.

8. Gruidl, M. E., and G. Mosig. 1986. Sequence and transcripts of the bacteriophage T4 DNA repair gene uvs Y. Genetics 114: 1061-1079.

9. Homyk, T., and J. Weil. 1974. Deletion analysis of two nonessential regions of the T4 genome. Virology 61:505-523.

10. Kassavetis, G. A., and E. P. Geiduschek. 1984. Defining a bacteriophage T4 late promoter: bacteriophage T4 gene 55 protein suffices for directing late promoter recognition. Proc.
Natl. Acad. Sci. USA 81:5101-5105.

11. Laemmli, U. K. 1970. Cleavage of structural proteins during the assembly of the head of bacteriophage T4. Nature (London) 227:680-685.

12. Macdonald, P. M., and G. Mosig. 1984. Regulation of a new bacteriophage T4 gene, 69 , that spans an origin of DNA replication. EMBO J. 3:2863-2871.

13. Mosig, G., D. W. Bowden, and S. Bock. 1972. E. coli DNA polymerase I and other host functions participate in T4 DNA replication and recombination. Nature (London) New Biol. 240:12-16.

14. Mosig, G., and A. M. Breschkin. 1975. Genetic evidence for and additional function of phage $\mathrm{T} 4$ gene 32 protein: interaction with ligase. Proc. Natl. Acad. Sci. USA 72:1226-1230.

15. Neidhardt, F. C., and R. A. VanBogelen. 1987. Heat shock response, p. 1334-1345. In F. C. Neidhardt, J. L. Ingraham, K. L. Low, B. Magasanik, M. Schaechter, and E. Umbarger (ed.), Escherichia coli and Salmonella typhimurium: cellular and molecular biology. American Society for Microbiology, Washington, D.C

16. Osawa, T., and T. Yura. 1981. Effects of reduced amount of RNA polymerase sigma factor on gene expression and growth of Escherichia coli: studies of the rpo D 40 (amber) mutation. Mol. Gen. Genet. 184:166-173.

17. Rabussay, D. 1983. Phage-evoked changes in RNA polymerase, p. 167-173. In C. K. Matthews, E. M. Kutter, G. Mosig, and P. B. Berget (ed.), Bacteriophage T4. American Society of Microbiology, Washington, D.C.

18. Riva, S., A. Cascino, and E. P. Geiduschek. 1970. Coupling of late transcription to viral replication in bacteriophage $\mathrm{T} 4$ development. J. Mol. Biol. 54:85-102.

19. Skelly, S., T. Coleman, C.-F. Fu, N. Brot, and H. Weissbach. 1987. Correlation between the 32-kDa sigma factor levels and in vitro expression of Escherichia coli heat shock genes. Proc. Natl. Acad. Sci. USA 84:8365-8369.

20. Snustad, D. P., L. Snyder, and E. Kutter. 1983. Effects on host genome structure and expression, p. 40-55. In C. K. Matthews, E. M. Kutter, G. Mosig, and P. B. Berget (ed.), Bacteriophage T4. American Society for Microbiology, Washington, D.C.

21. Taylor, W. E., D. E. Straus, A. D. Grossman, Z. F. Burton, C. A. Gross, and R. Burgess. 1984. Transcription from a heatinducible promoter causes heat shock regulation of the sigma subunit of $E$. coli RNA polymerase. Cell 38:371-381. 
22. Thomas, P. S. 1980. Hybridization of denatured RNA and small DNA fragments to nitrocellulose. Proc. Natl. Acad. Sci. USA 77:5201-5205.

23. Tilly, T., and C. Georgopoulos. 1982. Evidence that the two Escherichia coli groE morphogenetic gene products interact in vivo. J. Bacteriol. 149:1082-1088.

24. Wiberg, J. S., M. F. Mowrey-McKee, and E. J. Stevens. 1988. Induction of the heat-shock regulon of Escherichia coli markedly increases production of bacterial viruses at high tempera- tures. J. Virol. 62:234-245.

25. Yamamori, T., T. Osawa, K. Ito, and T. Yura. 1982. Escherichia coli gene (hin) controls transcription of heat shock operons and growth at high temperatures, p. 131-137. In M. Schlessinger, M. Ashburner, and A. Tissiers (ed.), Heat shock from bacteria to man. Cold Spring Harbor Laboratory, Cold Spring Harbor, N.Y.

26. Zografi, Y. N. 1981. On the role of the Escherichia coli RNA polymerase sigma factor in T4 phage development. Mol. Gen. Genet. 183:557-558. 